\title{
PENGATURAN BATAS WAKTU PENDAFTARAN \\ JAMINAN FIDUSIA PADA UNDANG-UNDANG \\ NOMOR 42 TAHUN 1999
}

\section{GEDE PRIMA PRAJA SARJANA}

\begin{abstract}
This article have title is "The Arrangement of Time Limit of Registration of Fiducia Guarantee in the law number 42 in 1999 on fiducia guarantee”. The issue in this article on how is Arrangement of Time Limit of Registration of Fiducia Guarantee in the law number 42 in 1999 on fiducia guarantee.

This study is normative law research. That is law research that based on secondary data (literature data). The approach have been applied in this study were statue approach that is the law number 42 in 1999 on fiducia guarantee, fact approach, and analytic and conceptual approach. Then analysis technique was by using descriptive, interpretation and argumentation.

The result showed, first: the law number 42 in 1999 on fiducia guarantee start from article 11 until 18. it is not clearly describe on time limit of registration of fiducia guarantee, so that it can arise uncertainty of law. Recommendation can be submitted that in order to demand of law certainty, orderliness, and useful in order to protect the public as user of fiducia guarantee institution, hence limit time of registration of fiducia guarantee need to be arranged strickly in the Law number 42 in 1999 on fiducia guarantee.
\end{abstract}

Keywords: Arrangement of time limit, registration of fiduci, fiducia guarantees. 
PENDAHULUAN

$\begin{array}{ccll} & \text { Bangsa } & \text { Indonesia } & \text { hingga } \\ \text { saat } & \text { ini } & \text { masih } & \text { sedang }\end{array}$

melaksanakan pembangunan dalam berbagai bidang, termasuk pembangunan dibidang ekonomi yang mengalami perkembangan cukup pesat.Namun demikian, masih banyak sektor-sektor pembangunan ekonomi yang masih harus dibenahi, termasuk salah satu diantaranya adalah menyangkut permodalan usaha.

Dalam dunia usaha modal sangatlah penting, dan tanpa itu sangat mustahil kegiatan dunia bisnis dan ekonomi dapat berjalan dengan baik. Modal usaha dimaksud dapat diperoleh melalui berbagai cara, salah satunya adalah melalui fasilitas kredit yang disediakan oleh dunia perbankan dan lembaga-lembaga pembiayaan non bank. Fasilitas kredit inilah menjadi salah satu tumpuan dunia usaha untuk memperkuat struktur permodalan dari kegiatan usaha yang dijalankannya.

Fasilitas kredit yang diberikan oleh bank, umumnya selalu meminta atau mensyaratkan adanya jaminan kebendaan sebagai jaminan tambahan.Istilah Jaminan berasal dari kata jamin yang berarti tanggung, sehingga jaminan dapat diartikan sebagaitanggungan. . Jaminan tersebut dapat diberikan oleh pihak ketiga dalam arti pihak ketiga tersebut memberikan jaminan kepada kreditur untuk memenuhi kewajiban debitur apabila debitur tidak mampu untuk memenuhi kewajiban terhadap utangnyatersebut atau dapat juga diberikan dalam bentuk barang yang setara dengan uang yangdipinjamkan oleh kreditur. Dalam kaitannya dengan hal ini,

\footnotetext{
${ }^{1}$ Oey Hoey Tiong, 1985, Fidusia Sebagai Jaminan Unsur-Unsur Perikatan, Cet. II,Ghalia Indonesia, Jakarta, h. 14.
} 
pihak debitur akan menyerahkan hak kebendaan yang dimilikinya untuk dijadikan jaminan atas kredit yang diterimanya. Apabila dikemudian hari debitur wanprestasi, maka benda jaminan tersebut akan dieksekusi untuk melunasi utang-utang debitur tersebut.

Ketika suatu benda milik debitur dijadikan jaminan kredit, maka akan dibuatkan perjanjian pengikatannya yang disebut dengan perjanjian pembebanan atau pengikatan jaminan.

Perjanjian pembebanan jaminan ini bersifat sebagai perjanjian tambahan (ikutan) yang mengikuti perjanjian pokoknya yaitu perjanjian kredit (perjanjian utang piutang). Perjanjian pengikatan jaminan ini tidak akan ada apabila tidak ada perjanjian pokok (perjanjian kredit).

Bila suatu benda akan diikatkan sebagai jaminan kredit, maka pembebanan atau pengikatannya akan sangat tergantung pada jenis bendanya. Apabila bendanya benda tidak bergerak, seperti tanah, maka pengikatannya

berdasarkan

Undang-Undang No. 4 Tahun 1996 dengan

Hak

Tanggungan.Sedangkan apabila bendanya benda bergerakatau benda tidak bergerak yang tidak dapat dibebani dengan hak tanggungan, maka pengikatannya berdasarkan Undang-Undang No. 42 Tahun 1999 memakai Fidusia.

Dalam praktek perbankan, jaminan fidusia tidak dapat dilepaskan dari masalah perkreditan. Sebagai jaminan kebendaan dalam praktek perbankan, masyarakat cenderung memilih jaminan fidusia karena memberi manfaat bagi masyarakat yang membutuhkan pendanaan/kredit masyarakat kecil dan menengah, pertokoan, pengecer, pengrajin, rumah makan, usaha pertanian, sangat merasakan kemudahan dengan fidusia sebagai jaminan kredit, karena fidusia memberikan pemanfaatan sepenuhnya barang jaminan oleh debitur, sehingga sangat membantu kelancaran proses produksi/operasional usahanya. Disisi perbankan, fidusia praktis 
dan tidak memerlukan tempat penyimpanan untuk barang-barang jaminan seperti pada lembaga gadai.

Pendaftaran jaminan

fidusia pada Kantor Pendaftaran

Fidusia yang merupakan lingkup tugas Kementerian Hukum dan Hak Asasi Manusia Republik Indonesia itu, secara tegas diatur didalam pasal 14 ayat (1) bahwa Kantor Pendaftaran Fidusia menerbitkan dan menyerahkan kepada Penerima Fidusia Sertifikat Jaminan Fidusia pada tanggal yang sama dengan tanggal penerimaan permohonan pendaftaran. Dan dalam hal permohonan pendaftarannya dilakukan oleh penerima fidusia, kuasa atau wakilnya dengan melampirkan pernyataan pendaftaran fidusia seperti yang tercantum pada Pasal 13 ayat (1) UU No. 42 Tahun 1999 tentang Jaminan Fidusia. Selanjutnya pada pasal 13 ayat (2) ditentukan pernyataan pendaftaran yang dimaksudkan dalam ayat (1), memuat sebagai berikut :

a. Identitas pihak Pemberi dan Penerima Fidusia b. Tanggal, nomor akta Jaminan Fidusia, nama, dan tempat kedudukan notaris yang memuat akta Jaminan Fidusia

c. Data perjanjian pokok yang dijamin fidusia

d. Uraian mengenai benda yang menjadi objek Jamin an Fidusia

e. Nilai penjaminan

f. Nilai benda yang menjadi obyek Jaminan Fidusia

Dalam pelaksanaannya sesuai dengan penjelasan pasal 13 ayat (3) yang menyatakan bahwa Kantor Pendaftaran Fidusia dalam hal menerima permohonan pendaftaran jaminan fidusia tidak melakukan penilaian terhadap kebenaran yang dicantumkan dalam pernyataan pendaftaran jaminan fidusia, akan tetapi hanya melakukan pengecekan data sebagaimana dimaksud dalam pasal 13 ayat (2).

\section{Berdasarkan ketentuan}

pasal 5 ayat (1) UU No. 42 Tahun 1999 tentang Jaminan Fidusia, pembebanan benda dengan jaminan fidusia dibuat dengan akta notaris. 
Selanjutnya berdasarkan ketentuan

Pasal 11 ayat (1), ditentukan bahwa benda yang dibebani dengan jaminan Fidusia wajib didaftarkan.

Dari kedua ketentuan pasal tersebut, menunjukkan bahwa pembebanan jaminan fidusia dilakukan dengan akta otentik, yaitu akta notaris, dan selanjutnya benda jaminan fidusia tersebut didaftarkan pada Kantor Pendaftaran Fidusia. Namun apabila akta jaminan fidusia tersebut tidak didaftarkan, tidak terdapat sanksi tegas yang diatur dalam Undang-Undang Jaminan Fidusia yang menyebabkan masih banyak bank atau finance hanya memproses obyek jaminan fidusia tersebut sampai pembuatan akta jaminan fidusia di Notaris saja. Sehingga menimbulkan polemik apakah pendaftaran akta jaminan fidusia wajib dilakukan atau tidak. Dalam praktek di masyarakat juga sering terjadi perjanjian kredit dengan jaminan fidusia yang obyeknya sudah dialihkan ke pihak ketiga sebelum didaftarkan, lalu selanjutnya baru didaftarkan ke Kantor Pendaftaran Fidusia, dan terhadap permohonan pendaftaran fidusia tersebut tidak dapat ditolak oleh Kantor Pendaftaran Fidusia. Hal yang demikian disebabkan dalam Undang-Undang tentang Jaminan Fidusia tidak diatur ketentuan mengenai daluarsa pendaftaran jaminan fidusia.

Seperti ditegaskan oleh Andreas Albertus Andi Prajitno dalam hasil penelitiannya bahwa jangka waktu kedaluarsa pendaftaran pada Fidusia tidak jelas. Sementara pada Hak Tanggungan ditetapkan 1 (satu) minggu sejak tanggal dibuatnya Akta Hak Tanggungan. ${ }^{2}$

Undang-undang jaminan Fidusia (Undang-Undang Nomor 42 Tahun 1999) pada ketentuan pasal 11 yang mengatur tentang pendaftaran Jaminan Fidusia, tidak mengatur secara jelas mengenai batas waktu pendaftaran sehingga menimbulkan ketidakpastian hukum. Dalam konteks ini tentu tidak selaras dengan tujuan dibuatnya Undang-Undang Fidusia demi terciptanya kepastian hukum,

${ }^{2}$ Andreas Albertus Andi Prajitno, 2010, Hukum Fidusia, Selaras, h. 119. 
kemanfaatan, dan ketertiban, dalam rangka mengayomi dan melindungi masyarakat pengguna lembaga fidusia.

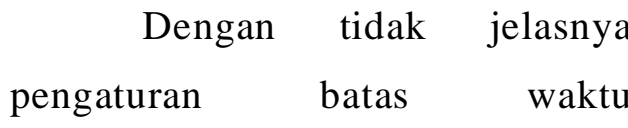
pendaftaran jaminan Fidusia ini mewujudkan adanya norma yang kabur (vage normen), padahal perumusan norma dalam suatu undang-undang harus jelas. Kekaburan norma tersebut dalam praktek aka menimbulkan ketidak pastian hukum dan bahkan konflik hukum. ${ }^{3}$

Dalam suatu UndangUndang menurut H. Tan Kamelo, kepastian hukum meliputi salah satunya adalah menyangkut kepastian norma dan prinsip hukum yang tidak bertentangan satu dengan yang lainnya baik dari pasal-pasal undang-undang itu secara keseluruhan maupun kaitannya dengan pasal-pasal lainnya yang berada diluar undangundang tersebut. ${ }^{4}$

${ }^{3} I b i d$, h. 113.

${ }^{4}$ H. Tan Kamelo, 2006, Hukum Jaminan Fidusia, Suatu Kebutuhan Yang Didambakan, Alumni, Bandung, h. 117.
Ketika Undang-Undang Fidusia rumusan normanya tidak jelas, terutama yang menyangkut batas waktu pendaftaran jaminan fidusia, maka dalam praktek menimbulkan permasalahan hukum karena ada pendaftaran jaminan fidusia yang dilakukan setelah terjadinya wanprestasi dari debitur. Dengan adanya permohonan pendaftaran jaminan fidusia setelah debitur wanprestasi tersebut sudah barang tentu pihak Kantor Pendaftaran Fidusia tidak bisa menolaknya karena dalam undang-undang tidak ditentukan secara tegas mengenai batas waktu pendaftaran tersebut, sehingga memberi kesan setiap saat bisa dilakukan pendaftaran atas jaminan fidusia tersebut.

Sebagaimana telah dikemukakan di atas yang menjadi fokus permasalahan adalah mengenai bagaimana pengaturan tentang batas waktu pendaftaran jaminan fidusia pada undangundang nomor 42 tahun 1999 tentang jaminan fidusia.Tujuan penelitian ini Untuk dapat 
menganalisisbagaimana pengaturan tentang batas waktu pendaftaran jaminan fidusia.

\section{METODE PENELITIAN}

Penelitian dalam kaitannya dengan penulisan artikel ini termasuk katagori jenis penelitian hukum normative, yaitu suatu prosedur penelitian ilmiah untuk menemukan kebenaran berdasarkan logika keilmuan dari sisi normatif. ${ }^{5}$ Bahan hukum yang dipergunakan dalan penelitian ini terdiri dari bahan hukum primer, bahan hukum sekunder, dan bahan hukum tertier. Bahan hukum dimaksud dapat diuraikan sebagai berikut :

1. Bahan hukum primer ; yaitu bahan hukum yang mempunyai kekuatan mengikat Yakni asas dan kaidah hukum yang berupa peraturan perundang-undangan maupun hukum yang tidak

Soerjono Soekanto, 1985 , Penelitian Hukum Normatif Suatu Tinjauan Dingkat, CV. Rajawali, Jakarta, h.15. tertulis yang berkaitan dengan permasalahan dalam penelitian ini yang meliputi Kitab Undang-Undang Hukum Perdata, Undang-Undang Republik Indonesia Nomor 42 Tahun 1999 tentang Jaminan Fidusia, dan Peraturan Pemerintah Nomor 86 Tahun 2000 tentang Tata Cara Pendaftaran Jaminan Fidusia dan Biaya Pembuatan Akta Jaminan Fidusia.

2. Bahan hukum Sekunder; yaitu bahan hukum yang memberikan penjelasan terhadap bahan hukum primer, yaitu meliputi ; buku-buku, literature, artikel, makalah dan bahan-bahan tertulis lainnya yang merupakan karangan para ahli hukum.

3. Bahan hukum Tertier; yaitu hukum yang memberi petunjuk maupun penjelasan terhadap bahan hukum primer dan bahan hukum sekunder, yaitu; berupa kamus hukum dan kamus bahasa indonesia.

Dalam penulisan ini dipergunakan pendekatan 
perundang-undangan (The Statue

Approach), pendekatan fakta (The

Fact Approach) dan pendekatan analisa konsep hukum (Analytical and Conceptual Approach).

Permasalahan penulisan ini dikaji dengan mempergunakan interprestasi dan argumentasi hukum berdasarkan teori azas dan konsep hukum yang relevan dengan permasalahan penelitian.

\section{HASIL DAN PEMBAHASAN}

\section{Mekanisme}

Pendaftaran

\section{Jaminan Fidusia}

Untuk kepastian hukum, ketentuan Pasal 11 UndangUndang Jaminan Fidusia (UndangUndang Nomor 42 Tahun 1999) mewajibkan benda yang dibebani dengan jaminan fidusia didaftarkan pada Kantor Pendaftaran Fidusia. Kewajiban ini tetap berlaku meskipun kebendaan yang dibebani dengan jaminan fidusia berada di luar wilayah negara Republik Indonesia. $^{6}$

${ }^{6}$ Gunawan Widjaja \& Achmad Yani, 2000, Jaminan Fudusia, PT. Radja Grafindo Persada, Jakarta, h. 139.
Kantor Pendaftaran Fidusia sebagai tempat pendaftaran Fidusia, untuk pertama kalinya didirikan di Jakarta dengan wilayah kerja yang menckaup seluruh wilayah negara Republik Indonesia. Secara bertahap, sesuai keperluan, di Ibu Kota Propinsi di seluruh wilayah Negara Republik Indonesia.

$\begin{array}{rrr}\text { Dalam } & \text { hal } & \text { Kantor } \\ \text { Pendaftaran } & \text { Fidusia } & \text { belum }\end{array}$
didirikan di tiap daerah Tingkat II (Kabupaten/Kota), maka wilayah kerja Kantor Pendaftaran Fidusia di Ibu Kota Propinsi meliputi seluruh Daerah Tingkat II (Kabupaten/Kota) yang berada di lingkungan wilayahnya. Pada saat sekarang, pendaftaran Jaminan Fidusia menjadi kewenangan Kantor Wilayah Propinsi Kementerian Hukum dan HAM yang ada di seluruh Indonesia.

Terkait dengan Pendaftaran Jaminan Fidusia, dikeluarkan Peraturan Pemerintah Nomor 86 Tahun 2000 tentang Tata Cara Pendaftaran Jaminan Fidusia dan Pembuatan Akta Jaminan Fidusia. Kantor Pendaftaran Jaminan 
Fidusia (Kantor Wilayah Hukum dan HAM Propinsi) menerima permohonan pendaftaran Jaminan Fidusia, menerbitkan, dan menyerahkan sertifikat Jaminan Fidusia.

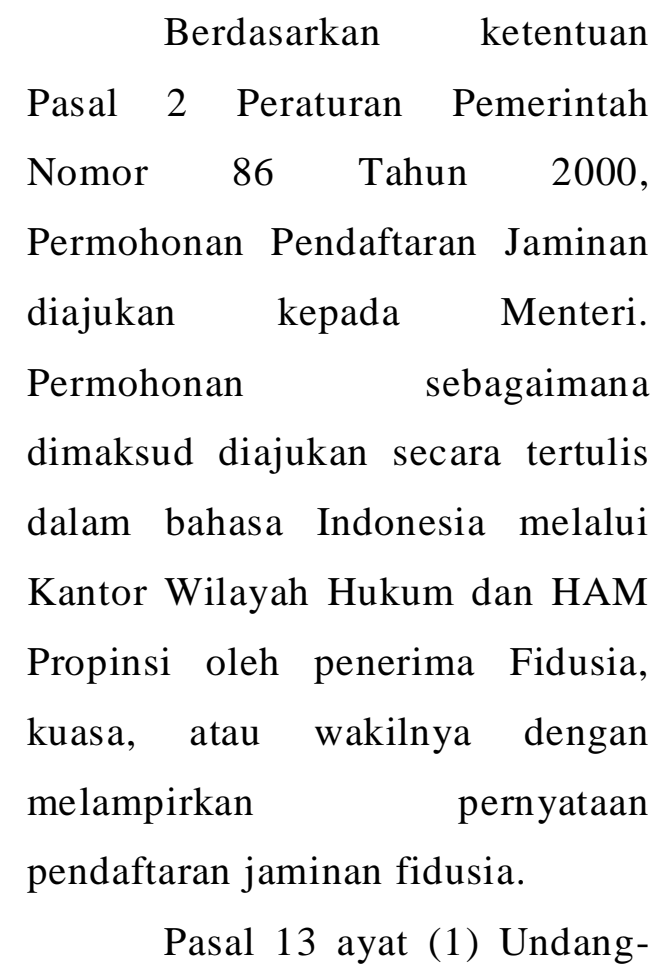

Undang Fidusia menentukan pula, bahwa permohonan pendaftaran Jaminan Fidusia tidak harus dilakukan oleh Penerima Fidusia, melainkan dapat dilakukan kuasa atau wakil dari Penerima Fidusia. Kuasa disini adalah mereka yang menerima pelimpahan wewenang berdasarkan surat kuasa dari Penerima Fidusia untuk melakukan Pendaftaran Jaminan Fidusia.
Adapun wakil disini adalah mereka yang berdasarkan ketentuan peraturan perundang-undangan berwenang untuk melakukan pendaftaran Jaminan Fidusia.

$$
\text { Pejabat }
$$

Pendaftaran Jaminan Fidusia pada Kantor Pendaftaran Fidusia yang menerima permohonan pendaftaran Jaminan Fidusia, berdasarkan ketentuan Pasal 3 Peraturan Pemerintah Nomor 86 Tahun 2000, kemudian memeriksa kelengkapan persyaratan permohonan pendaftaran Jaminan Fidusia yang telah ditetapkan. Kelengkapan persyaratan disini meliputi kelengkapan dokumen yang ditetapkan dan ketepatan dalam mengisi formulir sesuai dengan data yang diperlukan. Dalam hal ini Pejabat Pendaftaran Jaminan Fidusia tidak melakukan penilaian terhadap kebenaran yang dicantumkan dalam pernyataan pendaftaran dalam formulir Pernyataan Pendaftaran Jaminan Fidusia.

Apabila permohonan pendaftaran Jaminan Fidusia yang diajukan tersebut, tidak memenuhi 
kelengkapan persyaratan, Pejabat

Pendaftaran Jaminan Fidusia harus segera dan langsung mengembalikan berkas permohonan pendaftaran Jaminan Fidusia kepada pemohon untuk dilengkapi. Namun sebaliknya bila kelengkapan persyaratan permohonan pendaftaran Jaminan Fidusia telah dipenuhi dan dinyatakan lengkap, permohonan pendaftaran Jaminan Fidusia segera dan langsung diproses sebagaimana mestinya, dengan cara membubuhkan nomor, tanggal, dan jam penerimaan pendaftaran Jaminan Fidusia pada formulir Pernyataan Pendaftaran Jaminan Fidusia.

Adapun data-data yang harus didaftarkan tersebut, dengan sendirinya sudah dituangkan dalam formulir Pernyataan Pendaftaran Jaminan Fidusia sebagaimana ditentukan Pasal 13 ayat (2) Undang-Undang Fidusia. Hal-hal yang dinyatakan dalam formulir Pernyataan Pendaftaran Jaminan Fidusia tidak lain daripada datadata yang sudah dimuat dalam akta Jaminan Fidusia sebagaimana diatur dalam Pasal 6 UndangUndang Fidusia. Dalam formulir Pernyataan Pendaftaran Jaminan Fidusia dimuat hal-hal berikut :

a. Identitas pihak Pemberi Fidusia;

b. Identitas pihak Penerima Fidusia;

c. Tanggal, nomor Akta Jaminan Fidusia;

d. Nama dan tempat kedudukan notaris yang membuat Akta Jaminan Fidusia;

e. Data perjanjian pokok (perjanjian utang piutang) yang dijamin fidusia;

f. Uraian mengenai benda yang menjadi objek jaminan fidusia;

g. Nilai penjaminan; dan

h. Nilai benda yang menjadi objek Jaminan Fidusia.

Karena akta Jaminan Fidusia merupakan akta autentik, sebenarnya cukup dikatakan, bahwa pernyataan pendaftaran harus dilengkapi dengan salinan akta autentik penjaminan fidusia. Hal ini berkaitan dengan masalah pendaftaran ikatan jaminan fidusiabukan benda jaminan fidusiasehingga semua klausul yang 
termuat dalam perjanjian
penjamiinan fidusia, turut
terdaftar, agar mempunyai daya
mengikat pihak ketiga. ${ }^{7}$ Apabila seluruh persyaratan pendaftaran sudah dipenuhi, maka selanjutnya diterbitkan sertifikat jaminan fidusia. Pasal 4 ayat (2) Peraturan Pemerintah Nomor 86 Tahun 2000 selanjutnya menyatakan bahwa penerbitan sertifikat jaminan fidusia dan penyerahannya kepada pemohon dilakukan pada tanggal yang sama dengan tanggal pencatatan permohonan pendaftaran jaminan fidusia.

Dalam hal terdapat kekeliruan dalam sertifikat Jaminan Fidusia yang telah diterima oleh pemohon, dalam jangka waktu paling lambat 60 (enam puluh) hari setelah menerima sertifikat tersebut pemohon memberitahukan kepada Kantor Pendaftaran Fidusia untuk diterbitkan sertifikat perbaikan.

${ }^{7}$ Rachmadi Usman, 2009, Hukum Jaminan Keperdataan, Sinar Grafika, Jakarta., h. 211.
Sertifikat perbaikan dimaksud memuat tanggal yang sama dengan tanggal sertifikat semula. Penerbitan sertifikat perbiakan tersebut tidak dikenakan biaya (Pasal 5 ayat 1 , ayat 2, dan ayat 3 Peraturan Pemerintah Nomor 86 Tahun 2000).

Begitu juga dalam hal sertifikat Jaminan Fidusia hilang, rusak, penerima Fidusia, Kuasa, atau wakilnya dapat mengajukan permohonan sertifikat pengganti kepada Menteri. Permohonan sebagaimana dimaksud diajukan secara tertulis dengan melampirkan kelengkapan data yang diperlukan (Pasal 10 ayat 1 dan ayat 2 Peraturan Pemerintah Nomor 86 tahun 2000).

Setelah melalui proses dengan melampirkan seluruh persyaratan yang diperlukan, maka kemudian diterbitkan sertifikat pengganti. Sertifikat penggnati dimaksud diberi nomor dan tanggal yang sama dengan nomor dan tanggal sertifikat yang rusak atua hilang. Penyerahan sertifikat pengganti dilakukan pada tanggal 
yang sama dengan tanggal permohonan sertifikat pengganti.

Batas Waktu Pendaftaran Jaminan Fidusia.

Sebagaimana telah dipaparkan diatas, procedure pembebanan jaminan fidusia ada 2 tahapan yang sangat penting, pertama; pembuatan akta fidusia dan kedua; pendaftaran jaminan fidusia.Pembebanan fidusia terhadap jaminan bila pemegang/penerima fidusia hanya membuat aktanya saja dan tidak mendaftarkannya, maka tidak ada artinya, ${ }^{8}$ Fidusia baru lahir setelah dilakukan pendaftaran ke Kantor Departemen Hukum dan HAM (tepatnya setelah data-data dalam perjanjian Fidusia tercatat dalam Daftar Buku Fidusia). ${ }^{9}$
Pendaftaran

Fidusia

merupakan kewajiban hukum.

Tujuan pengaturan yang mewajibkannya
${ }^{8}$ Gatot Supramono, 2009, Perbankan dan Masalah Kredit Suatu Tinjauan Bidang Yuridis, PT. Rineka Cipta, Jakarta.h. 242..

9 Andreas Albertus Andi Prajitno, Op.Cit, h. 122. pendaftaran akta jaminan fidusia, yakni sebagai berikut :

1. Untuk memberikan kepastian hukum kepada para pihak yang berkepentingan.

2. Memberikan hak yang didahulukan (preferent) kepada penerima fidusia terhadap kreditur lainnya.

3. Dalam rangka memenuhi azas publisitas.

Terkait dengan masalah pendaftaran jaminan fidusia seperti diatur mulai pasal 11 sampai dengan pasal 18 Undang-Undang Fidusia sama sekali tidak mengatur tentang batas waktu pendaftaran jaminan fidusia atau tidak diatur mengenai daluwarsa pendaftaran jaminan fidusia, sehingga disini menimbulkan adanya ketidakpastian hukum.

Batas waktu pendaftaran atau jangka waktu daluwarsa pendaftaran jaminan fidusia tidak jelas, sedangkan pada UndangUndang Nomor 4 tahun 1996 tentang hak Tanggungan 1 (satu) minggu sejak tanggal dibuatnya akta hak tanggungan. Ketentuan pasal 13 ayat (1) dan ayat (2) Undang- 
Undang Hak Tanggungan menyatakan sebagai berikut: ${ }^{10}$

(1) Pemberian Hak Tanggungan wajib didaftarkan pada Kantor Pertanahan.

(2) Selambat-lambatnya 7 (tujuh) hari kerja setelah penandatanganan akta pemberian Hak Tanggungan sebagaimana dimaksud dalam Pasal 10 ayat (2), PPAT wajib mengirimkan Akta Pemberian Hak Tanggungan yang bersangkutan dan warkat lain yang diperlukan kepada kantor Pertanahan.

Selanjutnya penjelasan pasal 13 ayat (1) Undang-Undang Hak Tanggungan menyatakan ;

Salah satu Azas Hak Tanggungan adalah azas publisitas, oleh karena itu didaftarkannya pemberian Hak Tanggungan merupakan syarat mutlak untuk lahirnya Hak Tanggungan tersebut dan mengikatnya Hak Tanggungan terhadap pihak ketiga.

\footnotetext{
${ }^{10}$ Kartini Muljadi dan Gunawan Widjaja, 2005, Hak Tanggungan, Prenada Media, Jakarta, h. 213.
}

Dari ketentuan penjelasan Pasal 13 (ayat (1) tersebut di atas, maka pemberi Hak Tanggungan harus atau wajib diikuti dengan tindakan pendaftaran dalam Buku Tanah di Kantor Pertanahan, yang merupakan persyaratan mutlak bagi lahirnya Hak Tanggungan sekaligus mengikatnya Hak Tanggungan terhadap pihak ketiga. $^{11}$

Dengan tidak diaturnya mengenai batas waktu pendaftaran pada jaminan fidusia, maka membuka peluang untuk mendaftarkan jaminan fidusia itu kapan saja sesuai dengan kepentingan pihak kreditur.Kondisi seperti ini merupakan salah satu kelemahan atau kekurangan dari penormaan Undang-Undang Fidusia (Undang-Undang Nomor 42 Tahun 1999).Kendala yuridis dapat muncul bila ketidakpastian ini tidak segera disikapi.

Adanya ketidakpastian hukum mengenai batas waktu pendaftaran ini akan membawa 454. 
dampak negatif dalam praktek pinjam-meminjam dengan jaminan fidusia. berdasarkan pemahaman terhadap teori hukum yang bersifat refleksi pada obyek yang berupa bahan hukum yang diteliti, pembuatan aturan perundangundangan sepreti itu patut disayangkan karena sangat ceroboh dan melanggar sistem penormaan. ${ }^{12}$

$$
\text { Dalam konteks ini }
$$

kepastian hukum, kemanfaatan, dan ketertiban menjadi menjauh, sementara dibuatnya peraturan hukum tersebut (Undang-Undang Fidusia) adalah demi untuk terciptanya kepastian hukum, kemanfaatan, dan ketertiban serta mengayomi dan melindungi masyarakat pengguna lembaga jaminan fidusia. ${ }^{13}$

Seperti dikemukakan Sudikno Mertokusumo, kepastian hukum merupakan salah satu syarat yang harus dipenuhi dalam suatu penegakan hukum.Kepastian hukum adalah azas dalam Negara

12 Andreas Albertus Andi Prajitno, Op.Cit, h. 120.

${ }^{13}$ Andreas Albertus Andi Prajitno Loc.Cit. hukum yang merupakan landasan peraturan perundang-undangan. ${ }^{14}$

Begitu juga bila dikaitkan dengan fungsi dari hukum sebagai kaedah disamping menjamin keadilan sosial dan berfungsi mengayomi, melindungi, juga berfungsi menjamin kepastian hukum. ${ }^{15}$

Undang-Undang Fidusia sebagai suatu peraturan hukum atau peraturan perundangundangan hendaknya dapat merumuskan secara jelas tentang batas waktu pendaftaran jaminan Fidusia, seperti ditegaskan oleh Fuller, salah satu syarat dari suatu peraturan perundang-undangan dimana peraturan tersebut hendaknya dirumuskan secara jelas, artinya disusun dalam rumusan yang dapat dimengerti ( $a$ failure to make rule understandable). ${ }^{16}$

\footnotetext{
${ }^{14}$ Soedikno Mertokusumo, 1999, Mengenal Hukum Sebuah Pengantar, Liberty, Yogyakarta h. 145

${ }^{15}$ Bachsan Mustafa, 2003, Sistem Hukum Indonesia Terpadu, PT. Citra Aditya Bakti, Bandung, h. 20.
} 


\begin{abstract}
Dalam rangka ketertiban
dimasyarakat, maka rumusan

Undang-Undang Fidusia harus

jelas dan memenuhi kepastian

hukum.

Sebagaimnana

dikemukakan oleh Moch.Isnaeni,

hukum ingin menciptakan

kepastian hukum dalam hubungan

antara orang-orang dalam

masyarakat, dan untuk itu terlebih

dahulu hukum (peraturan) itu harus

menciptakan suatu kepastian pula

dalam tubuh peraturan itu sendiri. ${ }^{17}$
\end{abstract}

\section{KESIMPULAN DAN SARAN}

\section{Kesimpulan}

Berdasarkan

uraian

sebagaimana telah dipaparkan di

atas maka dapat disimpulkan

sebagai berikut:

Proses pendaftaran jaminan

fidusia diatur dalam Pasal 11

sampai dengan Pasal 18 Undang-

Undang Nomor 42 tahun 1999

tentang Jaminan Fidusia. Pada

${ }^{16}$ Lon. I. Fuller, 1963, The Morality of Law, Haven and London, Yale University Press, h. 39.

${ }^{17}$ Moch Isnaeni, 1996, Hipotik Pesawat Udara di Indonesia, $\mathrm{Cv}$. Dharma Muda, Surabaya, h.89 ketentuan pendaftaran jaminan fidusia tersebut tidak jelas diatur tentang batas waktu pendaftaran atau jangka waktu daluarsa pendaftaran jaminan fidusia tersebut. Berbeda dengan UndangUndang Nomor 4 tahun 1996 tentang Hak Tanggungan ketentuan tentang batas waktu pendaftaran Hak Tanggungan diatur secara tegas 1 (satu) minggu sejak tanggal dibuatnya Akta Hak Tanggungan. Dengan tidak jelasnya pengaturan batas waktu pendaftaran jaminan fidusia tersebut menimbulkan ketidakpastian hukum, sementara dibuatnya peraturan fidusia tersebut justru untuk menciptakan kepastian hukum, kemanfaatan dan ketertiban, serta mengayomi dan melindungi masyarakat pengguna lembaga fidusia.

\section{Saran-Saran}

Dalam rangka tuntutan kepastian hukum, ketertiban, dan kemanfaatan serta dalam upaya melindungi masyarakat pengguna lembaga jaminan fidusia, maka batas waktu pendaftaran jaminan fidusia perlu diatur secara tegas 
dalam Undang-Undang Nomor 42

tahun 1999 tentang Jaminan

Fidusia. Adanya praktek

pendaftaran jaminan fidusia setelah

debitur wanprestasi justru dipicu oleh tidak jelasnya mengenai batas waktu atau daluwarsa dari pendaftaran jaminan fidusia itu sendiri.

\section{DAFTAR BACAAN}

Oey Hoey Tiong, 1985, Fidusia Sebagai Jaminan UnsurUnsur Perikatan, Cet. II,Ghalia Indonesia, Jakarta

Andreas Albertus Andi Prajitno, 2010, Hukum Fidusia, Selaras, Malang.

H. Tan Kamelo, 2006, Hukum Jaminan Fidusia, Suatu Kebutuhan Yang

Didambakan, Alumni, Bandung

Soerjono Soekanto, 1985, Penelitian Hukum Normatif Suatu Tinjauan Dingkat, CV. Rajawali, Jakarta,
Gunawan Widjaja \& Achmad Yani, 2000, Jaminan Fudusia, PT. Radja Grafindo Persada, Jakarta

Rachmadi Usman, 2009, Hukum Jaminan Keperdataan, Sinar Grafika, Jakarta

Gatot Supramono, 2009, Perbankan dan Masalah Kredit Suatu Tinjauan Bidang Yuridis, PT. Rineka Cipta, Jakarta.

Kartini Muljadi dan Gunawan Widjaja, 2005, Hak Tanggungan, Prenada Media, Jakarta,

Soedikno Mertokusumo, 1999, Mengenal Hukum Sebuah Pengantar, Liberty, Yogyakarta

Bachsan Mustafa, 2003, Sistem Hukum Indonesia Terpadu, PT. Citra Aditya Bakti, Bandung 
Lon. I. Fuller, 1963, The Morality of Law, Haven and London, Yale University Press,

Moch Isnaeni, 1996, Hipotik Pesawat Udara di Indonesia, Cv. Dharma Muda, Surabaya,

\section{Peraturan Perundang-Undangan}

Peraturan Pemerintah Nomor 86

Tahun 2000 tentang Tata

Cara Pendaftaran Jaminan

Fidusia dan Biaya

Pembuatan Akta Jaminan

Fidusia.

Undang-Undang Republik

Indonesia Nomor 42 Tahun

1999 tentang Jaminan

Fidusia

\begin{tabular}{|c|c|c|}
\hline Undang-Undang & & Republik \\
\hline Indonesia & Nomor & 4 Tahun \\
\hline 1996 & tentang & $\mathrm{H}$ \\
\hline
\end{tabular}

